Varia 



\title{
The Sacred Object: Anne Carson and Simone Weil
}

\author{
Elizabeth Coles
}

\begin{abstract}
Este artículo examina la relación entre la lectura crítica y el objeto crítico en la obra de la poeta y ensayista canadiense Anne Carson, principalmente los textos que surgen de su largo acercamiento a los escritos de la filósofa y mística cristiana Simone Weil. Mi lectura de Carson se centra en los deseos conflictuales de la relación crítica que se encuentran confesados y no confesados en su obra, y en las formas de intimidad que sus respuestas logran con la obra de Weil. Agudizadas por su encuentro con el pensamiento y la fe de Weil, las preguntas de Carson para la crítica - sobre sus propios objetos y la resistencia de ellos a la interpretación, sobre la distinción entre crítica y literatura, y sobre la vanidad de la estética de la crítica misma- encuentran su articulación en varios géneros de la escritura: estudiando la complicidad de cada uno de estos con Weil, y la capacidad de cada uno a radicalizar sus cuestiones, llego a unas conclusions propias para la crítica literaria.
\end{abstract}

PALABRAS ClaVE: Anne Carson, Simone Weil, interpretación, crítica literaria, poesía contemporánea, teología, misticismo.

This paper examines the relationship between critical reading and the critical object in the work of the contemporary Canadian poet and essayist Anne Carson, principally the texts that emerge from her long-standing engagement with the writings of philosopher and Christian mystic Simone Weil. My reading of Carson addresses the conflicting desires of critical relationship that go confessed and unconfessed in her work, and the forms of intimacy her responses are able to achieve with the Weil oeuvre. Sharpened by their encounter with Weil's thinking and with her faith, Carson's questions for criticism -on its own objects and their resistance to interpretation, on the criticism/literature distinction, and on the vanity of criticism's aesthetics - find articulation in various genres of writing. Studying the complicity of each of these with Weil 
and the capacity of each to radicalize her concerns, brings my paper toward some conclusions of its own for literary criticism.

KEYWORDS: Anne Carson, Simone Weil, interpretation, literary criticism, contemporary poetry, theology, mysticism.

Fecha de recepción: 29 de agosto de 2013

Fecha de aceptación: 18 de septiembre de 2013 
Elizabeth Coles

Universidad Nacional Autónoma de México

Instituto de Investigaciones Filológicas ${ }^{1}$

\section{The Sacred Object: Anne Carson and Simone Weil}

Think of the Greek preposition $\pi$ pòs. When used with the accusative case, this preposition means "toward, upon, against, with, ready for, face to face, engaging, concerning, touching, in reply to, in respect of, compared with, according to, as accompaniment for." It is the preposition chosen by John the Evangelist to describe the relationship between God and The Word in the first verse of the first chapter of his Revelation:

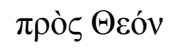

"And The Word was with God" is how the usual translation goes. What kind of withness is it?

AnNe Carson, Economy of the Unlost

The intimacy of God and Word is a conversation of one and a solitude of two. Inside the full line from John 1:1 ("In the beginning was The Word, and The Word was with God, and The Word was God"), "with"

${ }^{1}$ Postdoctoral Research Fellow, Postdoctoral Scholarships Program of the Coordinación de Humanidades, Universidad Nacional Autónoma de México. 
ripples out in both directions like a question: what is this moment of recognition, a flash of eye contact inside the monad of God and Word? "Face to face, engaging, concerning, touching" and finally "withness" is how the Canadian poet, critic and scholar Anne Carson describes the event. Yet the question to which she leads us - "what kind of withness is it?"- is not addressed to the theologian, the philosopher or even to the reader of the critical work in which it appears- Economy of the Unlost: Reading Simonides of Keos with Paul Celan (1999). ${ }^{2}$ The question, Carson hints earlier on in her short and casuistic preface, "Note on Method", is for "academic writing":

There is too much self in my writing. Do you know the term Lukács uses to describe aesthetic structure? Eine fensterlose Monade. I do not want to be a windowless monad - my training and trainers opposed subjectivity strongly, I have struggled since the beginning to drive my thought out into the landscape of science and fact where other people converse logically and exchange judgments - but I go blind out there. So writing involves some dashing back and forth between that darkening landscape where facticity is strewn and a windowless room cleared of everything I do not know. [...] Lukács is prescribing a room for aesthetic work; it would be a gesture of false consciousness to say academic writing can take place there. And yet, you know as well as I, thought finds itself in this room in its best moments - locked inside its own pressures... (Economy of the Unlost, vII).

The question "withness" is engaged to ask in Economy of the Unlost is what kind of relationship academic writing assumes over, against and with its objects of desire, a question Carson folds back onto the book itself at the point of its own defining "with" -Economy of the Unlost: Reading Simonides of Keos with Paul Celan. A critique of the finesses of "thought", "subjectivity" and "aesthetic work" in the relationships

${ }^{2}$ The word "withness" appears again in Carson in a more directly theological sense. In her poem "God's Christ Theory", Christ's incarnation is received "Not [as] passion but com-passion. / Com-means "with." / What kind of withness would that be?" See Anne Carson, Glass, Irony and God 51. Also see André Furlani's discussion of Economy of the Unlost in "Reading Paul Celan with Anne Carson: 'What kind of withness would that be?", Canadian Literature, 176 (Spring 2003), 84-104. 
of academic writing spool out of Carson's reference to John the Evangelist. In this paper I propose a deeper complicity in Carson between certain problems of theology and certain problems of criticism as she sees and perhaps also does not see them, a complicity staged in Carson's ongoing poetic and critical reading of the French philosopher and Christian mystic Simone Weil (1909-1943). The questions Carson asks of the practices of criticism and academic writing are, like the questions I will be asking here, sharpened and radicalized both by Carson's reading of Weil and by the dilemmas of mystical thinking that shape them: dilemmas for the writer and especially the critic, and for the objects of critical and religious desire.

The paper is divided into three sections. The first outlines Carson's critical response to Simone Weil in a reading of one of Carson's most recent critical essays, "Decreation" (2005). This homage to Weil's concerns, I suggest, finds itself curiously at home in Carson's wider critical project. The second section of the paper explores Weil's own thought on the question of interpretation as a relationship, and argues for the coincidence of Weil and Carson on a point that has more to offer critical practice than mystic theology. Weil's response to an absent object - the Judeo-Christian God- offers a way of thinking about what is at stake in interpreting "present" ones in literary criticism and critical aesthetics; her place in Carson's reflections on critical relationship also begs the question of what God and mystic theology are doing in contemporary, materialist and what we might call post-faith critical thought. The final section considers what Carson's poetic response to Weil achieves that her critical writing does not and perhaps cannot. At the heart of both forms of response is an effort to know and preserve literary objects of desire in the act of writing about them, a concern shared by Weil's preoccupations with an object whose secrecy or outright absence inspires comparable practices of desire and belief.

\section{I}

Carson is known perhaps first and foremost for her formal experimentation. It is commonplace in Carson to find the functions of poem and 
essay (as we might expect them) changing places: essays in verse as well as academic prose, and poems doing the work of literary criticism. "People make trouble out of that border [between poetry and its interpretation]. I practically don't separate them", she confesses in an interview: "I put scholarly projects and so-called creative projects side-byside in my workspace and I cross back and forth between them or move sentences back and forth between them, and so cause them to permeate one another" (Kevin McNeilly, "Gifts and Questions", 14). Having said this, few commentaries on Carson's work go beyond description of the fact of her formal or generic "hybridity". ${ }^{3}$ In Carson's relatively slim reception to date, it appears as though a poet who is also a scholar makes only a formal gesture when she imports the rigours and dilemmas of scholarship into a work of verse, or when a work of scholarship swaps expository language for a language closer to its critical object's - as is so often the case in Carson. ${ }^{4}$ On their own, the formal qualities of this formal interpenetration tell us very little about Carson's project as a critic and, for that matter, as a poet; yet they are the vocabulary of a critical ethics at the heart of Carson, one that binds her project to the worldly and otherworldly ethics of Simone Weil.

In Economy of the Unlost, the "withness" of Simonides of Keos and Paul Celan - and of Carson's own critical accompaniment of the pairis presented as a matter of attention: "Attention is a task we share, you and I. To keep attention strong means to keep it from settling. Partly for this reason I have chosen to talk about two men at once. They keep each other from settling, they are side by side in a conversation and yet no conversation takes place" (Economy of the Unlost, VIII). The methodological announcement, ambivalently received in reviews of the work, serves Carson's tentative definitions (and the book's less tentative actions) of what criticism should be doing: keeping its object from

${ }^{3}$ See Ian Rae, "Dazzling Hybrids”, Canadian Literature, 166 (Autumn 2000), 1743. Rae considers the formal and generic qualities of Carson's verse novel Autobiography of Red (1998). See also Ian Rae, From Cohen to Carson: The Poet's Novel in Canada.

${ }^{4}$ An exception is André Furlani, "Reading Paul Celan with Anne Carson: 'What kind of withness would that be?"”, 84-94. 
"settling". ${ }^{5}$ At stake, Carson announces, is the kind of contact criticism is - between the critic and the objects of her attention, and between those objects as they meet and touch in the critical work. She writes of a fear of insular and self-regarding subjectivity in criticism - "Eine fensterlose Monade. I do not want to be a windowless monad." - yet in the space Lukács tells us is proper to aesthetic work (to poetry and not, we imagine, to criticism in this case), Carson places her critical reading of Celan and Simonides. ${ }^{6}$

At once abashed and luxuriant, Carson's confession invites us to believe in her critical project as a deliberate and fully self-conscious form of intimacy (both with and between Celan and Simonides), and suggests this intimacy is not only a personal necessity but a matter of critical quality —of thought's "best moments". Carson's intimacy persuades at the level of sound, symbol and rhythm as her readings of critical objects momentarily take on their poetics, mimicking and extending their ways of meaning. ${ }^{7}$ The same windowlessness (a form of intimacy and enclosure critiqued inside Lukács's materialism) is a proud feature

${ }^{5}$ See e.g. Elizabeth Lowry's review of Economy of the Unlost, "The man who would put to sea on a bathmat", London Review of Books, Lowry praises Carson's critical project but attacks the casuistic "Note on Method" as "staggeringly pretentious", "a parody of the worst kind of academic preciousness". See also Steven J. Willet's review in Bryn Marw Classical Review (2000. 02. 28), accessed on 20.11.2012 at http://bmcr. brynmawr.edu/2000/2000-02-28.html. Willet accuses Carson of academic "hubris" in her comparative work.

${ }^{6}$ Carson references Lukács's treatise on aesthetics "Die Subjekt-Objekt Beziehung in der Ästhetik", published in the journal Logos in 1917. Lukács's writings on Modernism (including "The Ideology of Modernism" in The Meaning of Contemporary Realism, and Realism in Our Time: Literature and the Class Struggle ) discuss the socio-political possibilities offered by Realism to politically insular "aesthetic work". For discussion of Lukács on Modernism see Eugene Lunn, Marxism and Modernism: an Historical Study of Lukács, Brecht, Benjamin, and Adorno.

${ }^{7}$ Carson's reading of Celan's "Matière de Bretagne" replicates the poem's aural and visual palette, its store of images and its metrical pulse, releasing them as the poem's "own" critical resource. "The poem", she says, "has the rhythm of a bloodsail, sailing forward in waves from gorselight to gorselight to you". The poem guides Carson's critical vocabulary as the "rhythm of a bloodsail" ["das Blutsegel"] —the poem's distinctive dactylic pulse - continues in "gorselight to gorselight to you". Carrying the pulse of Celan's "the bloodsail is heading for you" ["das Blutsegel hält auf dich zu"], Carson's "Redder than red, redder than the blood of a boar in a dream" does not directly quote but rather inhabits the same "dream" as the poem. 
of Carson's readings of Simone Weil, the lyrist Sappho and the French fourteenth-century mystic Marguerite Porete in "Decreation", an essay whose leading concern is precisely this form of intimacy. Yet the essay, Carson's most forceful theorization to date of "withness" and the relationships of writing, inherits its strictures and arguments from writers whose object of desire and interpretation is a divine one. ${ }^{8}$

Carson's compendium of poetry, critical essays and opera libretti, Decreation (of which "Decreation" is the title essay) is named after one of Simone Weil's most conspicuous and least comprehensible terms, "décréation". The closest we come to a definition of "décréation" in Weil is:

[...] to make something created pass into the uncreated (faire passer du créé dans l'incréé). An imaginary divinity has been given to man so that he may strip himself of it like Christ did of his real divinity. [...] We participate in the creation of the world by decreating ourselves (Gravity and Grace, 32-33; La Pesanteur et la grace, 36). ${ }^{9}$

In the case of relationship to God, decreation asks for the undoing of the subject because her presence to the object - God- is too substantial. The problem of "too much self" that Carson sets out in Economy of the Unlost is one of Weil's constitutional concerns, a condition of Creation (and creation) that can be reimbursed, as Weil has it. However, while in Economy of the Unlost "too much self" is a justification of the author's

\footnotetext{
${ }^{8}$ Theorizations of a similar nature to "withness" include Martin Heidegger's Mitsein (Being-with), Paul Celan's Begegnung (encounter) and Martin Buber's Ich-Du relationship set out in Martin Buber, I and Thou,. See also Martin Heidegger, Being and Time, 154-156, and Edith Silbermann, Begegnung mit Paul Celan: Erinnerung und Interpretation.

${ }^{9}$ The term is a neologism coined by Charles Péguy, though Weil does not acknowledge this anterior use. The concept of décréation is often excluded from scholarly discussions of Weil's work on the basis of its abstraction and difficulty. An attempt to situate the term can be found in J. P. Little, "Simone Weil's Concept of Decreation", Simone Weil's Philosophy of Culture, 25-51. See also Miklos Veto, The Religious Metaphysics of Simone Weil, for one of the earliest and most rigorous discussions of décréation, and R. Kühn, "Le Monde comme texte. Perspectives herméneutiques chez Simone Weil", Revue des Sciences Philosophiques et Théologiques, 64: 4, 509-530 for a useful genealogy of the term in Maurice Blanchot, Paul Ricoeur and others.
} 
methodology, in Decreation the problem of "too much self" is less an indictment of Carson's own writing than a condition of writing per se.

Carson returns in Decreation to "withness" and, in doing so, returns the problem to the theological strictures in which it is first planted in her oeuvre: the "withness" of Word and God, and, more troublingly, the intimacy between words, God and the writer (Economy of the Unlost, vII). ${ }^{10}$ The book's title essay, "Decreation: How Women like Sappho, Marguerite Porete and Simone Weil Tell God", concerns itself with what Carson calls the problem of "telling". This problem seems at first to be strictly about praise: in Carson's first example, how can the lyric poet Sappho praise Aphrodite without herself getting in the way of praise? In Carson's second example, Marguerite Porete boasts the same ambivalence to herself as the giver and obstructor of praise, and consents to an ecstasy in which she separates from herself, permitting her to be "with" God without the "with": "And so long as I was at ease and I loved myself 'with' him I could not at all contain myself or have calm...I loved myself so much along 'with' him that I could not answer loyally", Carson quotes Porete, interpreting her "in bondage to Marguerite rather than to God" (Decreation, 165-166). ${ }^{11}$ Love of the divine object is obstructed by the natural self-love of subjectivity; "withness" is a problem because it means two and not one, a subject "with" an object. The scenario, Carson tells us, is also one of jealousy, though not in any straightforward sense: each writer is jealous of that presence that obstructs contact with the beloved object; in the cases of Sappho, Porete and Weil, that presence is herself.

Carson's essay has four parts. The first three introduce the ecstasies of Sappho, Porete and Weil, and the fourth - unannounced from the beginning - considers the problems of writing and "telling" in the three authors and elevates Carson's project to the same pitch. Writing, insofar as it takes part in the "theology of love" Carson describes, is seen as a

${ }^{10}$ See Carson, Glass, Irony and God, 51.

${ }^{11}$ The text Carson uses is the only extant text attributed to Marguerite Porete, $\mathrm{Le} \mathrm{Mi-}$ roir des simples âmes anéanties et qui seulement demeurent en vouloir et désir d'amour, English translations Carson adapts are Marguerite Porete, The Mirror of Simple Souls, trans. E. Colledge, J. C. Marler and J. Grant and Marguerite Porete: The Mirror of Simple Souls, trans. E. Babinsky. 
point of radical tension with the ethics, desires and designs of that love (Decreation, 162). Writing is first announced as a problem in a strikingly casuistic passage of Carson's essay:

Inasmuch as we are now entering upon the fourth part of a three-part essay, we should brace ourselves for some inconsequentiality. I don't feel the cause of this inconsequence is me. Rather it originates with the three women we are studying and the cause of it is the fact that they are writers. [...] How are we to square [their] dark ideas with the brilliant assertiveness of the writerly project shared by all three of them, the project of telling the world the truth about God, love and reality? The answer is we can't. It's no accident that Marguerite Porete calls her book a Mirror [The Mirror of Simple Souls]. To be a writer is to construct a big, loud, shiny centre of self from which the writing is given voice and any claim to be intent on annihilating this self while still continuing to write and give voice to writing must involve the writer in some important acts of subterfuge and contradiction (174).

"I don't feel the cause of this inconsequence is me" is an act of subterfuge and contradiction all of its own. If inconsequence is a feature of writing, Carson suggests, it is an inevitable one, yet the subterfuges of Carson's argument are not perhaps so inevitable. Carson introduces her presence by negating it, announcing the "big, loud, shiny centre of self" in whose glass we see Carson herself reflected, then occluding it by telling us that the inconsequence belongs to writing: the argument plays the hand it describes as a de facto trick of description, while Carson's own mirror trick exposes itself alongside those she points to, glinting inside the writing of Weil, Porete and Sappho as each dodges her own reflection in language.

Carson's turn in this dance of would-be self-withdrawal makes itself visible in the essay's structure. Her readings of Sappho, Porete and Weil are self-contained vignettes whose adjacency makes an argument: no case is explicitly made for their relatedness; no critical rigour or argumentative leads bind the three women together in the essay. As in Economy of the Unlost, the argument is meant, we understand, to make itself by virtue of the authors simply being together; the lines between them (to quote another of Carson's methodological confessions, this time 
preceding a set of poems) simply "draw themselves" (Carson, Plainwater, 93). Self-withdrawal continues at the level of language. The tone of the essay veers between understated, with a glaze of something like objectivity, and conversational, nodding personably toward the "I" of the critic. The strength and compulsion of Carson's "I", "me" and fantasy interlocutor "you" drives the opening of the essay: "What if I were to begin an essay on spiritual matters by citing a poem that will not at first seem to you spiritual at all?" Invitations and remarks to this fantasy interlocutor - "we", "let's", "us", alongside confessions of limitation such as "I don't want to give the impression I know what this verse is saying or that I see where the poem is headed from here, I don't"- suggest a casualness of reading that is a designed exposure of casualness, non-domination and "decreation", not by eliminating the confessional "I" but the sovereignty and implicit violence of its arguments.

While caught in precisely the problem it articulates, Carson's project of intimacy in interpretation succeeds most clearly at the level of language. As the section on Sappho comes to a close, Carson hones in on a logic within Sappho and asks and answers her own questions inside its terms. Inside the logic of "daring", taking its cue from the final broken lines of Sappho's "Fragment 31" ("But all is to be dared, because even a person of poverty"), Carson stretches the term to the outer edges of its assumptions: "pan tolmaton: all is to be dared" [...] leads us back to [Sappho's] ecstatic condition. For when an ecstatic is asked the question, What is it that love dares the self to do? She will answer: Love dares the self to leave itself behind, to enter into poverty" (Decreation, 162). A similar rhetorical intimacy is staged with Porete, as the figures of her writing - "jealousy", "divine pleasure without myself", "my sense failed me", "being which is being" and "faint[ing] away"- are knotted into Carson's own leading figure, "jealousy is a dance in which everyone moves". Carson is guided by the poetics of Porete: "And insofar as she can annihilate all these - her term - she can resolve the three angles of the dance of jealousy into a single nakedness and reduce her being from three to two to one". She argues not by exposition but by extension of poetic figures here, the intimacy of one language with another. The politics of this kind of writing are finally difficult to gauge: its ecstasy is the withdrawal of the author behind the vivid terms and logics 
of her object — something we might idealise by calling immanence or mystify by calling "withness" - but it is also the masking of a reading.

Carson makes the dilemma of the mystic the example par excellence of the inherent and inherently problematic personality of writing, yet her own gesture remains a problem. Marguerite Porete says: "For whoever talks about God... must not doubt but must know without doubt... that he has never felt the true kernel of divine Love which makes the soul absolutely dazzled without being aware of it ....and takes away absolutely the practice of telling" (Decreation, 162). In writing about God, the writer has to realize, Marguerite insists, that she is missing the point, that her awareness of the object is dazzled by the figures and characters of precisely that awareness, and not by the object: that the writer can be dazzled by the sense of her own writing. An essay about the forcefulness of subjectivity forces something through beneath its own self-confession, something we might call its lingering desire for itself: desire to say, to theorize, to collapse into the object it wishes to account for. Contradiction and the negotiation of desire is certainly a key part of the mystic's experience of writing about God, and one that Carson inherits; yet in opening up questions of writing's place in the dilemma, it serves the critic far more than it serves the mystic - in this case, we'll see, Simone Weil.

Turning to Weil, we see that while writing for Carson is so troublesome, it is far less so for Weil: "In the operation of writing", Weil says, "the hand which holds the pen and the body and soul attached to it are things infinitely small in the order of nothingness" (Decreation, 174). While Carson employs this quotation in an argument for the over-importance of the self in writing, Weil, we might say, accepts the lie of writing because the liar - the writer- is herself of small importance. Yet inside this acceptance is a second lie. The diminishing of the author is also the diminishing of history, politics and subjectivity: both lies offer us - just as they offer Carson- grounds for a confrontation of writing and critical practice. 
Weil's desire to know God beyond the subjective compound Weil-withGod takes its place in a lifelong negative theology theorized by Weil in her private notebooks, her posthumously published lectures on philosophy at a lycée in Le Puy, her lengthy correspondence with the Catholic priest, Father Jean-Marie Perrin, and the handful of works published in her lifetime. Carson quotes one of the most poignant passages of Weil's notebooks on precisely this concern: "If only I knew how to disappear there would be a perfect union of love between God and the earth I tread, the sea I hear..." (Decreation, 168-169). ${ }^{12}$ Weil is the "unwelcome third" ("le tiers importun") here: "placed between two lovers", she "ought to go away so that they can really be together" ("avec deux fiancés et doit s'en aller afin qu'ils soient vraiment ensemble", Gravity and Grace, 41). Her sensual apprehension of the world ("the earth I tread, the sea I hear") senses the potential of a union without herself. In Weil's ethics, self-withdrawal is a "tact[ful]" gesture, and one of immense grace - grace, Weil tells us that "fills spaces, but cannot enter except where there is a void to receive it" ("comble, mais elle ne peut entrer que là où il y a un vide pour la recevoir", La Pesanteur et la grace, 12). Culmination of the gesture of self-withdrawal, "void" here means denuding oneself of the capacity to imagine God, and for Weil this cull of imagination is crucial. ${ }^{13}$ Relating to God requires forms of subjectlessness and objectlessness, both of which offer ways of thinking about critical reading.

Weil asks the reader of God precisely not to read Him: "Try to love without imagining. To love the appearance in its nakedness and without interpretation. What one loves then is truly God" ("Essayer d'aimer sans imaginer. Aimer l'apparence nue et sans interprétation. Ce qu'on aime alors est vraiment Dieu" (Gravity and Grace, 54; La Pesanteur et la grâce, 61). To love without imagining here is to love without desiring, for to desire is to imagine the beloved and to seek an equivalent of

${ }^{12}$ Carson references Gravity and Grace, 88-89.

${ }^{13}$ Weil articulates her opposition to imagination in Gravity and Grace, in Waiting on God, and in her Lectures on Philosophy, 193. 
his image in a world where the beloved is not. Elsewhere in her notes, Weil proposes the "extinction of desire (Buddhism) —or detachmentor amor fati - or desire for the absolute good - these all amount to the same: to empty desire, finality of all content, to desire in the void, to desire without any wishes. To detach our desire from all good things and to wait" ("Détacher notre désir de tous les biens et attendre", Gravity and Grace, 13; La Pesanteur et la grâce, 15). Yet Weil"s case is not for desirelessness but for objectless desire - "to detach our desire", "to desire in the void, to desire without any wishes". Her plea for objectlessness recalls what Sigmund Freud calls "evenly suspended attention", desiring the analysand's content without wishing it to mean anything in particular. "14 "Wishes" here believe in and desire "finality of content", a finality that is the very source of Weil's anxiety about desire: desire makes the object something it is not; our tendencies to define, resolve and fix the object of desire are more concerned with the satisfaction of desire than with attention to its object. ${ }^{15}$

Weil takes the question of desire further still. The self-sensing quality of desire that reads in the object the fulfillment of its own wish can even create its own objects where originally there were none. This is of course especially true in the case of an absent God, but its lessons invite us to consider interpretation as relationship to something not entirely present to the critic or to the language he uses to describe it; to consider criticism as descriptions of a necessary estrangement from the work. Weil warns us against interpreting the divine object for two reasons: firstly, that to interpret (for Weil) is to interject deliberate fantasy between oneself and one's object; and secondly, that this object — by default and by necessity, Weil will argue - is absent. The impoverishment of subjectivity and the absence of the object seem to be conditional on each other for Weil: if we accept that God is absent to us, we also accept the limitation on our subjectivity with regard to sensing or interpreting Him; likewise, in accepting the limitation of subjectivity,

${ }^{14}$ See Sigmund Freud, "Recommendations to Physicians Practising Psycho-analysis", The Standard edition of the Complete Psychological Works of Sigmund Freud, vol. 12, 109-120.

${ }^{15}$ We can observe parallels with Theodor W. Adorno's critique of the self-complacency of criticism. See Theodor W. Adorno, Prisms, 27, 34; Aesthetic Theory, 440,423. 
renouncing the "faux" or "falsity" of imagination, God's absence to the world is a raw and vertiginous sensation. In Attente de Dieu (Waiting on God, 1950), she describes "a kind of horror [that] submerges the whole soul. During this absence there is nothing to love" (66). The twin voids of subject and object match each other in Weil's theology. The question arising out of this double impoverishment is how the object is sensed, and sensed as other than oneself, given the flattening out of subjectivity and the uncertain status of the object as object. So vehemently against its interpretation, Weil seems to be saying that the divine object must not be known, an unknowability that takes the question of its survival to a new level. We should then ask why this unknowable object comes to be prized over knowledge of it at all, and how, then, to write about it.

One of Weil's more curious notes on the subject goes as follows:

Attention is what seizes hold of reality, so that the greater the attention on the part of the mind, the greater the amount of real being in the object (Notebooks of Simone Weil, vol. 2, 527).

(Ce qui aisait la realité est l'attention, de sorte que plus la penseé est attentive, plus l'objet en est plein d'être) ${ }^{16}$

Attention is what makes an object real, she suggests: attention makes an object an object in the first place. Weil seems to say that real being or "plein d' être" (an alternative translation might be "fullness of being") is constituted at least in part in the subject's act of attending, a proposition that casts the object's autonomous being into doubt. Weil's syntax may be misleading here - it should be remembered that the quotation comes from a collection of personal notes, not a finished work- but she seems to be saying not that attention enables us to see more "real being" in the object, rather that attention causes the object's being to be. Invoking relation to God, Weil says that attention turns our awareness "onto that which cannot be conceived": attention gives us access to the inconceivable, but it also, if we follow what she says about "plein d'être", allows

${ }^{16}$ Simone Weil, "Cahiers (Juillet 1942- Juillet 1943)", Euvres complètes, 6 vols. (Paris: Gallimard, 1989-2006), vol. 4 (2006); “Cahier 3”, 174. 
us to conceive the inconceivable out of nothing (Notebooks of Simone Weil, vol. 1, 179).

Weil's equation of knowledge and fantasy leaves us in a difficult position. Her critique of divine knowledge suggests that a better way to sense the difference between ourselves and our objects of desire is to know nothing, to feel the force of nothing instead of fantasy. ${ }^{17}$ Relationship is pushed to its limits in Weil because she asks us to feel nothing - not something - as resistance. The dangers of this position in disciplines other than theology are, I think, too clear to need stating. ${ }^{18}$ Moreover it is difficult to see how Weil's ethics of interpretation translates into a critical ethics without falling into the trap of reading the "nothing" (objectlessness) of Weil's relationship with God as a cue to subjectivity to romp wherever it pleases because it encounters no limit, senses itself in "tension" with nothing. Yet Weil's position demands at least a brief reflection on what this "nothing" might mean for interpretation in the humanities: the value, perhaps, of recognizing what is not grasped, not resolved, not wanted, not yet even read, in the object of interpretation.

Weil returns to the question of this not-yet-object, this time focusing on the desires surrounding it:

Descend to the source of desires to wrench the energy from its object. It is there that desires are true insofar as they are energy. It is the object that is false. But there is an unspeakable wrench in the soul at the separation of a desire and its object.

If we descend into ourselves, we find that we possess exactly what we desire.

\footnotetext{
${ }^{17}$ The word "fantasy" comes with strong psychoanalytic associations, e.g. Freud's argument in Studies in Hysteria (1893) that the hysteric patient's fantasy of seduction and a "genuine" seduction mean the same for the patient, and are equally "real". Fantasy in the context of Weil's arguments would mean indifference to whether the object is, finally, real or not.

${ }^{18}$ We can see a similar though more worldly ethics in Emmanuel Levinas's Totality and Infinity: An Essay on Exteriority and Maurice Blanchot's The Infinite Conversation. In both texts, the irreducibility of the Other not only to my understanding of him but to my descriptions of that understanding (both of which are forms of totalization) is expressed as that Other's infinity.
} 
(Descendre à la source des désirs pour arracher l'énergie à son objet. C'est là que les désirs sont vrais en tant qu'énergie. C'est l'objet qui est faux. Mais arrachement indicible dans l'âme à la séparation d'un désir et de son objet.

Si l'on descend en soi-même, on trouve qu'on possède exactement ce qu'on désire ${ }^{19}$ (La Pesanteur et la grâce, 25).

The object of desire is a fantasy, says Weil, and one we possess because it comes from ourselves. For Weil, it is the energy of desire that in its imageless truth inhabits the world, while (the image of) the object has no existence outside our own imagination. It is not desire's energy that is autoerotic but the object of desire. At first glance, her final sentence betrays the sense it inherits from the previous and seems to translate as: we already possess this (false) object so have no need of another (genuine) one. Yet for Weil's theology, possessing this "false" object means radical incompletion. Having and knowing the object renders it automatically false, whereas the energy of desire for unknown quantities of the object is what is real for Weil. Desire for what in the work of art or literature remains estranged from the work of criticism, the very aspects that provoke desire because they remain apart from and irreducible to that desire, is the mode of critical subjectivity Weil's theology invites us to consider. ${ }^{20}$

The above are examples of how, for Weil, interpretation can turn nothing into something and something into something else. The question that brings Weil's theorizations more sharply into dialogue with Carson's project as a critic, however, is how these theorizations are written: in the texture and textuality of nothingness or the fullness, resolution and desire of which Weil and Carson both speak. In a typical

\footnotetext{
${ }^{19}$ Following Emma Craufurd, I use the pronoun "we", rather than the more precise translation "one". Other than this final sentence, I retain the syntactically rough notational style of Weil's original. See Gravity and Grace, 22.

${ }^{20}$ For Meister Eckhart and the traditions of mystical thought in his wake, communicable and incommunicable aspects of the divine were distinct categories with distinct theologies. See Denys Turner, The Darkness of God: Negativity in Christian Mysticism and Jacques Derrida on Eckhart's negative theology in Jacques Derrida, "How to Avoid Speaking: Denials", Languages of the Unsayable: The Play of Negativity in Literature and Literary Theory, 3-70, see especially 20, 52, 69 (note 28).
} 
passage from Weil's unedited notebooks, we see just how casuistic and enclosed Weil's logic can be:

God created me as a non-being which has the appearance of existing, in order that through love I should renounce this apparent existence and be annihilated by the plenitude of being [...] The 'I' belongs to non-being. But I have not the right to know this. If I knew it, where would be the renunciation? I shall never know it (First and Last Notebooks, 96-97).

Judging by the syntax alone, Weil seems to be thinking on the spot, improvising a dialectical logic. Yet as Sharon Cameron notes in a discussion of Weil's "impersonality", the "I" in this same passage has been deprived of its particularity; it is positional rather than substantive, far from the unguided and self-referring subject of improvisation. In her finished works, Weil's near-constant use of the pronoun "soi" (third person indefinite: an English equivalent is "one") marks a clear rejection of autobiography in favour of abstraction (Dargan, Simone Weil: Thinking Poetically, 5). Alongside Weil's cold authorial "I" is the fate to which she condemns it: an "I" deprived of the right to know that it is not. Following these theorizations, we might ask whether Weil's writing is a form of desire or possession or both, and to what extent, though "the hand which holds the pen and the body and soul attached to it are things infinitely small in the order of nothingness", the presence of desire and/ or possession can be felt in the operations of Weil's writing.

Scholars tend to agree that Weil's writing is impersonal, and that this impersonality is a form of decreation. ${ }^{21}$ Joan Dargan speculates: "Perhaps writing itself was for Weil a process of decreation - the poetic imagination employed in the service of an impulse toward the universal. [...] it is exclusive rather than inclusive, insofar as the presence of the speaker is concerned"(Simone Weil: Thinking Poetically, 5). This

${ }^{21}$ See Dargan, Simone Weil: Thinking Poetically, 5-9 and Sharon Cameron's "The Practice of Attention". Other discussions of Weil's impersonality include Claire Wolfteich, "Attention or Destruction: Simone Weil and the Paradox of the Eucharist", The Journal of Religion, 81:3 (July 2001), 359-376, and Christopher Hamilton, "Simone Weil's 'Human Personality': Between the Personal and the Impersonal", Harvard Theological Review, 98:2 (2005), 187-207. See also Gillian Rose's critique in "Angry Angels - Simone Weil and Emmanuel Levinas" which I discuss below. 
reading gives Weil's philosophy the benefit of the doubt, lets it off the hook with an argument for its internal coherence. Dargan suggests that although Weil's writing excludes its speaker -Weil herself- it is impelled to include on a universal level, to include all subjects (and by implication none) by not distinguishing between subjects at all.

As a reader, however, Weil desires the particular - the particularities of history, of subjects and of the author. Writing in L'Enracinement (The Need for Roots, 1949), she critiques the "so-called historical spirit [that] does not pierce the paper to find flesh and blood; it consists in a subordination of thought to the document" ("L'espirit dit historique ne perce pas le papier pour trouver de la chair et du sang; il consiste en une subordination de la pensée au document", 283). ${ }^{22}$ Another form of sovereignty, "the document" is used here as a critique of the reader, the "historical mind" who sees the text as a set of opaque facts, and as a critique of the workings of ideology on the flesh and blood of history: Weil instead asks us to "read between the lines to transport oneself fully" (283-284). In this model the reader is in charge, and yet Weil's desire for this "flesh and blood" - of the writer or of the written- alerts us to a struggle inside the rigours of decreation. This struggle is nowhere clearer than in the relationship between Weil's ethics and her way of writing.

In a section of Gravity and Grace titled "Readings" by Thibon, Weil's theory of reading is a vision of a universal right to interpret and be interpreted particularly, the opposite of which is domination: "Every being cries out silently to be read differently. We read, but also we are read by others [...]. Forcing someone to read as we read him (slavery)" (135). We might recall the way Carson's critical prose is guided by the logic and the poetics of its objects, and both the casuistries and clear successes of that gesture. Weil's theory of reading and the readability of her own writing are inconsistent with one another in different way. Arguing for Weil's commitment to "creative thought" and "the discernment of the reader", Dargan is critical of the appar-

${ }^{22}$ We can link Weil's assertion to Walter Benjamin's historical materialism: Benjamin notes around the same time that because of the "anonymous toil" of human flesh and blood, "there is no document of civilisation that is not also a document of barbarism". See Walter Benjamin, "Theses on the Philosophy of History”, Illuminations, 256. 
ently un-reader-friendly nature of Weil's prose: Weil's writing seems not allow in its reading for the kinds of creative freedom it sets out in theory. Dargan's problem with the Weil oeuvre is that the texts are "uninhabitable and there is no room for argument $[\ldots]$ one assents or one does not (Simone Weil: Thinking Poetically, 51)." In Weil's unaccommodating style "it is impossible to stay in one's own terms" (51). Her writing is so sure, so complete, that for all its sensitivity to forms of domination, its demand for the undoing of the creature, Weil's prose dominates its reader.

A more forceful and damning account of Weil's writing is the British philosopher Gillian Rose's essay “Angry Angels: Simone Weil and Emmanuel Levinas" (1993) in which she sets out Weil and Levinas's critiques of the other's faith - Christianity and Judaism (Judaism and Modernity, 211-223). Reading Weil's notes on Israel in La Pesanteur et la grâce and her essay "Human Personality" (1943) alongside Levinas's "Simone Weil Against the Bible" (1952), Rose explains that both critiques propose something about the other faith that the critique itself repeats: the "weak spot" shared by Levinas and Weil is the violence of their critique of the violence of faith. For Rose, Weil misreads Judaism as a faith of (and in) violence, projecting there her "confessional other"; Levinas's attack on Weil's Christianity projects a violence for which he criticises her: both, argues Rose, "expose the intrinsic violence of the sovereign individual towards herself, her others and towards God" (212) Their accounts fail as ethics because both "claim [...] violently that violence is cultivated elsewhere" (221).

Recalling Weil's own sensibilities, Rose proposes that "knowledge has this structure of sovereign and solitary violence" (215). Yet placing this Weilian understanding of knowledge and its discourses next to Weil's own imperative not to know, we find ourselves at a loss: how might we turn these lessons from Weil and her most erudite readers back onto the question of critical interpretation without taking them where Carson does in her essay on "Decreation" - without turning the problem into just another of thought's "best moments"? (Economy of the Unlost, VII). For Rose, both Weil and Levinas are phenomenologists of this structure of violence, of "the conflict of good and evil, of attention and force or of substitution and possession" (Judaism and Moder- 
nity, 219). ${ }^{23}$ Both reproduce in their mode of address the violence they seek to expose in the other, and yet:

Instead of confessing and configuring the paradox of authorship, each accuses the other faith of not allowing for the ever-threatening contamination of the Good by violence (212).

The "paradox of authorship" recalls the paradox or "problem of telling" that Carson attends and succumbs to in "Decreation": that writing both affirms and denies the author, and that her writing binds her to forms of resolution and definition that can close down productive forms of tension and meaning in the critical object. ${ }^{24}$ The absence of what she calls a "confession" in Weil is, for Rose, a clandestine form of violence; without it, and without the "humour and irony" essential to such a confession, the writer's careful and hermeneutically sensitive prose becomes a form of domination. Recalling Lukács's celebrated critique of description, "Narrate or Describe?" (1936), ${ }^{25}$ Rose rebukes Weil's discourse for its loftiness, its distance from "the world" and its failure to "suspend and resume the ethical with its features of modern state and society" (Judaism and Modernity, 221). ${ }^{26}$ The abstraction and otherworldliness of her ethics not only shuts down political or worldly

${ }^{23}$ With "attention", Rose refers to Weil"s Attente de Dieu; with "force", to Weil"s spectacular essay on the Iliad, "L"Iliade, ou le poème de la force" (1939-40), in which Weil theorises the conversion of beings into things in the phenomena of war.

${ }^{24}$ The "paradox of authorship" means more than this for Rose. In The Broken Middle, she writes that "The 'crisis' consists in having to take our bearings from the works and not, as we are prone to do, the works from our bearings - yet the work is determined to abandon its reader and dissolve its author." Gillian Rose, The Broken Middle 19.

${ }^{25}$ For Lukács, the problem is historical: the failure of description to announce "the relationship of observation to creation" - how experience becomes a communication- makes description complicit in the "artistry" of social ideology and prevents the subject from seeing his own implication in history. See Gyorgy Lukács, "Narrate or Describe?", Writer and Critic, 121.

${ }^{26}$ Rose is not alone in her criticism of Weil for suspending the political: in the same year as "Angry Angels" was published, the former Archbishop of Canterbury Rowan Williams flagged up the impoverishment of Weil's discourse on the human, the social and the political, while Richard $\mathrm{H}$. Bell alerted us to the irreconcilability of elements such as decreation to an ethics in the world. See Rowan Williams, "The Necessary nonexistence of God", Simone Weil's Philosophy of Culture, 52-76. 
dimensions but leaves her highly conspicuous, unable to "pass unnoticed" in the text (222). ${ }^{27}$ In "Our existence is made only out of [God's] waiting for our consent not to exist" ("Notre existence n'est faite que de son attente, de notre consentement à ne pas exister" La Pesanteur et la grâce, 36). ${ }^{28}$ Weil's discourse is out of reach, the exclusiveness/ all-inclusiveness of the "soi" or the universalising decree of the "notre" remain aloof to their own fallibility. Weil's spirituality is, for her, "the representation of the law" and her writing confirms it (Judaism and Modernity, 216). ${ }^{29}$ Whether hers is an exposition or a domination of the dilemma of telling depends, of course, on how we read Weil, on what we are able to do, finally, inside the law of her writing.

\section{III}

How might Weil's writing be written about without replicating precisely the tensions that produce this paradox —of writing that preserves its own cohort of violence while theorizing non-violence and nondomination? Rose has suggested that this "paradox of authorship" goes unconfessed in Weil, and that confession of the acts and strictures of writing might be a means of salvation from them. We saw in Carson's "Decreation" that merely stating as fact what she calls the "subterfuge and contradiction" of writing is not enough: that this form of naming slips all too smoothly into the subterfuge it describes, without interruption or - to use another of Rose's terms - "configuration" of its basic paradoxes.

Following Carson's essay on "Decreation", her opera libretto of the same name reprises the themes of the essay while taking these themes to another level. At this level, Weil's questions about interpretation and relationship are treated to a form of answer in the poetry of the li-

${ }^{27}$ quoting Gustave Thibon.

${ }^{28}$ For help with Weil's complicated syntax, I have consulted Craufurd's translation: Gravity and Grace, 32.

${ }^{29}$ We can contrast, for example, the exalted confessional "I" of other mystic writers including Marguerite Porete, St. Teresa of Avila, Meister Eckhart and Sor Juana Inés de la Cruz. 
bretto, which works as an alternative critical response to the concerns of Sappho, Porete and Weil. Like the essay, the three-part "Decreation" libretto divides its attention between themes deriving from the three authors. Moving between bathos and the high drama of a mystery play, "Love's Forgery", based on the "jealous" scenario of Sappho's "Fragment 31", casts Hephaistos and Aphrodite (to whose cult of worship Sappho is thought to have belonged) in a love triangle with Ares, the Greek god of war; the second part, "Her Mirror of Simple Souls", stages the trial and condemnation of Marguerite Porete by a chorus of papal inquisitors who indict Porete in Latin and English; and the final part, "Fight Cherries", dramatizes the final moments of Weil's life as a struggle with hunger and desire, set out in dialogues between Weil and her parents.

Even as it stages the extremes of desire, religious ecstasy and death by starvation, the opera is a work of supreme camp (titles of duets include "Duet of the Sleeveless Sports Blouses avec Maman", "Parental Interlude", "Aria of Last Cherries", to give an idea). Marguerite Porete and Simone Weil, both of whom feature in the opera's dramatis personae, deliver and distort tenets of their own work. In the "Decreation" essay Marguerite Porete is quoted ("Jealous he is truly! He shows it by his works which have stripped me of myself absolutely and have placed me in divine pleasure without myself' (164), whereas in the opera she is parodied:

$\mathrm{M}$ [arguerite Porete]: Jealous he is truly!

For he has parted me from myself

Absolutely

By a ravishing farness nearer than my own self!

$[\ldots]$

M: Jealous he is truly!

For he has annihilated me

as myself

absolutely

and born me new as nothingness in no self!

(210-211) 
Carson makes Marguerite Porete's points about the non-presence of God in an unraveled and rebound version of her language. The effect - parodic or guided by the mystic's own poesis - is the simultaneous saying and unsaying of Porete's own discourse, a representation of the hit and miss of critical response, and a movement in and out of the work that tests and pushes the boundaries between criticism and its object. The opera plays on a dialectic that belongs to critical reading: criticism desires the work of art while manipulating and sampling that work to the critic's advantage. Carson stages the desires and vanities of interpretation in her experiments with original texts, accompanying Porete, Sappho and Weil inside their own paradox of authorship - the paradox of their farness and nearness to the object of desire.

Carson works inside the paradox she defines for Weil in the "Decreation" essay: between desire for the object - God - and acceptance that such an object is by nature astray. True to this paradox, the "Fight Cherries" section of the libretto is reconstituted Weil ready for consumption as Carson, pulling and teasing Weil's language into parodies that confess themselves as somewhere between Weil and Carson, between a resistant object and a response that gives form to it, whatever subterfuge and contradiction that might involve. The libretto tours the theoretical highlights of the Weil oeuvre: "Imagination which fills up the void is essentially a liar"; "Grace can only enter where there is void to receive it" and so on, in duets between Carson's characters (226). Yet this saying is also the unsaying of Weil. Carson ties Weil's terms in knots, undoes them, turns them through word games, repetitions and rhetorical questions to the point of parody. Carson quotes a short (fabricated) letter from Weil to her mother:

"Chère Maman I have bought two sleeveless sports / blouses Today a street fight between Nazis and / Communists No I was not there! Please send / me special post what I asked for last / letter (the Hegel) Kisses". She proceeds to mix up the words until the coherence of the letter is lost, but other, dormant forms of sense emerge: "Chère Maman I was special there I / bought less Hegel Please Today have / Nazis send blouses between sports / I asked what Communists kissed / me for (two fight sleeves) / No not last post!'. 
By the end of the sequence, Carson's burlesque Weil announces to her mother: "No special Maman sport to the last / fight two less / kiss sleeves Today! / cher Hegel [...] I create myself by work. / Or else I panic - / that is to say, / chère Maman out of my way!" (233) Carson's parodies and misquotations romp inside the law of Weil's rigid decrees, testing that law, it seems, but also searching for something more essentially Weilian (or Carsonian) in its destruction.

Yet the point of this pastiche is perhaps more complex. Carson tells us in the prologue to "Fight Cherries" that Weil's letters home "are repetitions of the one same glowingly factitious postcard that every good daughter sends home": the mixing up and reconstitution of the letters represents a very particular act of evasion and a very particular absence of the object (Weil, Carson, Decreation, 223). In the context of Carson's discourse on telling, the manipulation of this fictitious text — and a variety of other near-quotations in the final part- speaks back to her "Decreation" essay as a response to its central problem: how the manifold attractions of writing can outdo the object of the writer's attentions, a problem that becomes acute in the case of God for whom the writing is up to a certain point a substitute. ${ }^{30}$ In the opera, the dialectic of two writings (Weil's and Carson's) is exposed by their closeness and by parody of the source text, yet the absurdity of Carson's burlesque interventions, the uses to which she puts Weil, disband her own authority as a writer and throw the status of the twin "Decreation" texts entirely askew. As the libretto uses and "comments" on the material of the essay, the two texts unsettle each other and disorient any reader who hopes to come away with a meaningful sense of what criticism and literary work are doing there, and how separable the two finally are.

Here, Carson is in fundamentally Weilian territory. Unlike the tensions, ironies and confessions of Carson's, Weil's writing does not turn the problem of her object's absence into its own feature. Yet the paradox of authorship that makes the writer by default too present and too ab-

${ }^{30}$ See Michel de Certeau's arguments on the Eucharist and other forms of incarnation, verbal and material: Michel de Certeau, The Mystic Fable: The Sixteenth and Seventeenth Centuries, 79. 
sent is at the centre of her theology. For Weil, the "I" is at once nothing and just too substantial, irrelevant and an obstruction to the object of her attention. For Carson, this theology inspires a critical practice with wide implications for criticism and interpretation: a critical practice that confesses and plays with its own role in reading, and a critical reader who senses, engages and believes in what evades her in the work, what resists before the interpretation is cast.

\section{REFERENCES}

Adorno, Theodor W, Prisms (1955), trans. S. Weber and S. Weber, Cambridge, Mass., Massachusetts Institute of Technology Press, 1983.

Adorno, Theodor W, Aesthetic Theory (1970), trans. Robert Hullot-Kentor, Minneapolis, University of Minnesota Press, 1997.

Benjamin, Walter, "Theses on the Philosophy of History", Illuminations, ed.

Hannah Arendt, trans. Harry Zohn, New York, Schocken, 1968.

Blanchot, Maurice, The Infinite Conversation (1969), trans. Susan Hanson,

Minneapolis, University of Minnesota Press, 1993.

Buber, Martin, I and Thou (1923), trans. Walter Kaufmann, Edinburgh, T. \& T. Clark, 1970.

Carson, Anne, Glass, Irony and God, New York, New Directions, 1995.

CARson, Anne, Plainwater: Essays and Poetry, Vintage Contemporaries, New York, Vintage, 1995.

CARson, Anne, Economy of the Unlost: Reading Simonides of Keos with Paul Celan, New Jersey, Princeton University Press, 1999.

Carson, Anne, Decreation: Poetry, Essays, Opera, New York, Jonathan Cape, 2005.

Dargan, Joan, Simone Weil: Thinking Poetically, Albany, SUNY Press, 1999.

De certeau, Michel, The Mystic Fable: The Sixteenth and Seventeenth Centuries (1982), trans. trans. Michael B. Smith, Chicago, University of Chicago Press, 1992.

DerRIDA, Jacques, "How to Avoid Speaking: Denials", Languages of the Unsayable: The Play of Negativity in Literature and Literary Theory, eds. S. Budick and W. Iser, Palo Alto, Stanford University Press, 1987.

Freud, Sigmund, "Recommendations to Physicians Practising Psycho-analysis" (1912), The Standard edition of the Complete Psychological Works of Sigmund Freud, ed. James Strachey; trans. James Strachey and Anna Freud, with Alix Strachey and Alan Tyson, 24 vols., London, Hogarth Press and the Institute of Psychoanalysis, 1953-1974, vol. 12, 109-120. 
Furlani, André, "Reading Paul Celan with Anne Carson: 'What kind of withness would that be?'”, Canadian Literature, 176, Spring 2003, 84-104.

Hamilton, Christopher, "Simone Weil's 'Human Personality': Between the Personal and the Impersonal", Harvard Theological Review, 98:2, 2005, 187-207.

HeIDEGGER, Martin, Being and Time (1927), trans. J. Macquarrie and E. Robinson, Oxford, Basil Blackwell, 1962.

KüHn, R, "Le Monde comme texte. Perspectives herméneutiques chez Simone Weil", Revue des Sciences Philosophiques et Théologiques, Paris, 64: 4, 1980, 509-530.

Levinas, Emmanuel, Totality and Infinity: An Essay on Exteriority (1961), trans. Alphonso Lingis, Pittsburgh, Duquesne University Press, 1969.

Little, J. P, "Simone Weil's Concept of Decreation", Simone Weil's Philosophy of Culture, ed. Richard H. Bell, Cambridge, Cambridge University Press, 1993.

Lowry, Elizabeth, "The man who would put to sea on a bathmat", London Review of Books, 22: 19, 5 October 2000.

LuKÁCs, Gyorgy, "Narrate or Describe?", Writer and Critic, ed. Arthur D. Kahn, London, Merlin Press, 1970.

LunN, Eugene, Marxism and Modernism: an Historical Study of Lukács, Brecht, Benjamin, and Adorno, Berkeley, University of California Press, 1984.

McNeILly, Kevin, "Gifts and Questions: An Interview with Anne Carson", $\mathrm{Ca}$ nadian Literature, 176, Spring 2003.

Porete, Marguerite, Le Miroir des simples âmes anéanties et qui seulement demeurent en vouloir et désir d'amour, ed. R. Guarnieri, Archivo Italiano per la Storia della Pietà 4, 1965.

Porete, Marguerite, The Mirror of Simple Souls, trans. E. Colledge, J. C. Marler and J. Grant, Notre Dame, Notre Dame University Press, 1999.

RAE, Ian, "Dazzling Hybrids", Canadian Literature, 166, Autumn 2000, $17-$ 43.

RAE, Ian, From Cohen to Carson: The Poet's Novel in Canada, Montreal, McGill-Queen's University Press, 2008.

Silbermann, Edith, Begegnung mit Paul Celan: Erinnerung und Interpretation, Aachen, Rimbaud Verlag, 1993.

Turner, Denys, The Darkness of God: Negativity in Christian Mysticism, Cambridge, Cambridge University Press, 1995.

Rose, Gillian, The Broken Middle, Oxford, Blackwell, 1992.

Rose, Gillian, Judaism and Modernity, Oxford, Blackwell, 1993.

Veto, Miklos, The Religious Metaphysics of Simone Weil (1971), trans. Joan Dargan, Albany, suny Press, 1994. 
WeIL, Simone, La Pesanteur et la grace, Paris, Plon, 1947.

WeIL, Simone, L'Enracinement, Paris, Gallimard, 1949.

WeIL, Simone, Attente de Dieu, Paris, La Colombe, 1950.

WeIL, Simone, Waiting on God, trans. Emma Craufurd, London, Routledge, 1951.

WeIL, Simone, Gravity and Grace, trans. Emma Craufurd, London, Routledge, 1952; repr. 2002.

Weil, Simone, Lectures on Philosophy (1959), trans. Hugh Price, Cambridge, Cambridge University Press, 1978.

WeIL, Simone, "Cahiers (Juillet 1942- Juillet 1943)", (1951), Euvres complètes, 6 vols., Paris, Gallimard, 1989-2006.

WeIL, Simone, Notebooks of Simone Weil, 2 vols, trans. Arthur Wills, Routledge Kegan Paul, 1956.

WeIL, Simone, First and Last Notebooks, trans. Richard Rees, Oxford, Oxford University Press, 1978.

Willet, Steven J, review in Bryn Marw Classical Review (2000. 02. 28), accessed on 20.11.2012 at http://bmcr.brynmawr.edu/2000/2000-02-28.html.

WiLliams, Rowan, “The Necessary non-existence of God", Simone Weil's Philosophy of Culture, ed. Richard H. Bell, Cambridge, Cambridge University Press, 1993.

Wolfteich, Claire, "Attention or Destruction: Simone Weil and the Paradox of the Eucharist", The Journal of Religion, 81:3, July 2001, 359-376. 